\title{
Chapter 3 \\ R. F. Holland: Absolute Ethics and the Challenge of Compassion
}

\author{
HEIDI NORTHWOOD
}

The complete egoist then is a man of 'absolute conceptions'. In this way the problem of false semblances makes an inroad into the nature and style of absolute conceptions. ${ }^{1}$

In the moral dilemmas that are so often used in undergraduate ethics courses, students are confronted with a choice between 'doing the right thing', which has horrible consequences, and doing something which seems wrong but has a 'happier' result. In this way, these dilemmas appear almost to be primers for consequentialist thinking. Given the way such examples are usually set up, students are forced to find sense in choosing 'the lesser of the two evils'.

In his article 'Absolute Ethics, Mathematics and the Impossibility of Politics', R. F. Holland ${ }^{2}$ considers such an example from Bernard Williams. Twenty South American Indians are about to be executed for protesting the policies and actions of the current government. An honored visitor arrives and is given a choice:

$\ldots$ the captain is happy to offer him a guest's privilege of killing one of the In-
dians himself. If Jim accepts, then as a special mark of the occasion, the other
Indians will be let off. Of course, if Jim refuses, then there is no special occa-
sion, and Pedro here will do what he was about to do ...

According to what Holland calls 'consequentialist ethics', the answer is obvious: kill the one Indian. We must put aside our moral scruples and make the tough decisions that come with living in the world. We don't have the luxury of remaining true to those moral absolutes we learned in Sunday school; those are for the lucky. In the real world things are much more complicated than that; in the real world we need to make compromises. 
Holland, however, doesn't find this line of thought convincing. Instead, goodness is something absolute and requires the renunciation of what Holland calls the 'relative ends' of the world. With an absolute ethics, in contrast to any form of consequentialism, some things simply cannot be done, despite one's desire to fix, to help. Despite the tug one may feel to make the best of a horrible situation, one must forego actions like killing the one Indian, with the unhappy result that one may seem to be left with no plausible options at all:

... the difficulty [such dilemmas] present is exacerbated by the kind of consistency that an absolute ethics demands, to the point of seeming to render the agent's position completely hopeless; whereas the consequentialist invariably hopes to bring about something. ${ }^{4}$

Indeed, given such 'seeming hopelessness', it might be thought that Holland should be arguing for a kind of retreat from the world so that such conflicts would not arise. If absolute ethics and living in the world cannot be reconciled, perhaps it would be best to find that sheltering wall and let the dust and dirt fly by. But this is not what Holland believes. Elsewhere, ${ }^{5}$ in discussing Kierkegaard's idea of an eternal resolution, ${ }^{6}$ Holland considers a kind of retreat that some have found possible, what he calls 'seemingly the most radical form of renunciation of the relative ends of the world': 'sitting motionless in a monastery'. ${ }^{7}$ But in this discussion, as in his discussion of Williams' example, Holland seems to reject this kind of retreat. Agreeing with Kierkegaard, he writes, 'The rejection of relative ends must be encompassed . . . in action, not through inactivity'. ${ }^{8}$ This seems to leave open the possibility of a kind of withdrawal from the world - one that will not amount to 'inactivity' - that Holland would not reject. But to withdraw from the world so as to resolve conflicts occasioned by an absolute ethics is, Holland writes, impossible:

For you do not start with a clean sheet: there will already be commitments, to preserve institutions and to look after individuals, and since you cannot do this if you retreat, what is being contemplated puts you in a dilemma. If you find yourself obliged to abdicate you are involved in a moral contradiction. ${ }^{9}$

Where to retreat is to abdicate one's responsibilities to others, this will be to fail in one's (absolute) commitments. Retreating, then, is no salvation 
from the dilemmas, for these absolute commitments to others will be part of what one must honor if one is to be good.

But if one cannot retreat and be at the same time good, and yet one also cannot kill the Indian and so make the best of a bad situation, what is left? What is one to $d o$ ? Is one just supposed to stand there and watch the captain kill all twenty men? Holland raises the question himself: Could the visitor 'be as good a person as it is possible to conceive' and either shoot the Indian or decline? ${ }^{10}$ Holland says 'no'. But it is not that he offers a clear directive for alternative action. Instead, he points out that the example itself is flawed (as, no doubt, he would say that all such examples are flawed). The fanciful nature of it and of all other examples of its kind hides 'the source of the sense of outrage at being asked to contemplate' it. ${ }^{11} \mathrm{He}$ continues:

The sort of make-believe involved is different from that which occurs when a playwright of the stature to do it shows us something from which we can learn. When Shakespeare for example presents characters imaginatively in their entanglements with evil, our sense of the reality of our own relationship to both evil and good is heightened, whereas here we are drawn into an exercise of fancy about just that relationship. It is a kind of temptation: that is what the revulsion is about. ${ }^{12}$

In the example Williams offers, we are made to believe that both alternatives in the dilemma are equally problematic. This is because we are offered the consequences of both alternatives, which is completely fanciful since, of course, we can never know the consequences of our actions beforehand. Thus we become distracted from the action itself, whether it is good or evil, and our decision is removed from real life. As such it has nothing to teach us and we are led to treat ethical choices as if they were problems of arithmetic.

On the other hand, if the example were transformed into something closer to life, something closer to what we find in great literature, then it might cease to have the two equally unpalatable choices. If, for example, who the visitor is - what kind of a man he is - were included, the example would cease to have the character of a mere calculation. Imagine, Holland writes, that the visitor is a saint. While he is clear that predicting what a saint would say or do in such circumstances 'goes against the grain', if only because the saint is not concerned with consequences, Holland nonetheless 
offers some possibilities of just the sort that the example in its abstract form hides from us:

I suppose that maybe he would manage somehow to take the place of the one Indian; or if he could not get himself shot instead of him, perhaps he would make sure that he was shot along with him or else as the first of the twenty. That is if the Captain had not thus far been given pause, for there is what a saint might say to be thought of as well as what he might do, and being spoken to by a saint would not be like being spoken to by an ordinary person; so perhaps it would not then be so much a matter of what the Captain might or might not do, as what the men in his company were prepared to do, and what the bystanders might be moved to do, after having seen and heard the saint. ${ }^{13}$

This is to transform the example from clean to messy, from abstract to real - where people interact and so can learn from one another, and as such it can show us something, but not something specific about what action should be taken. Instead, we might come to understand something of what it is to be good. ${ }^{14}$

Absolute ethics, then, requires of at least most of us that we stay in the world, in the thick of it. It requires that we attempt to be good and do the good, using as our models such moral heroes as saints. It requires that we forego those actions which would involve us in compromising our absolutes and so compromising with evil. Holland is inspiring here, I think. The thought experiment he proposes to us not only shows us what is wrong with moral dilemmas of the kind so often used in classrooms, but also makes clear why so many characters in literature - characters like Socrates in the Apology, Crito, and Phaedo, and Iphigenia in Euripides' Iphigenia in Tauris - are so moving. They are so because they can show us true goodness; and conversely, they can show us where evil really resides. They can awaken our desire to be good and do the good.

But, again, all of this comes with a price. In not being willing to make compromises in order to make a bad situation 'good', we open ourselves up to 'limitless suffering':

The moral geometry which puts the doing of evil outside the agent's limit, while providing him with infinite space in which to suffer when others do it, puts a limitation also on the good that he can achieve. Much that would otherwise have been possible, especially the most spectacular, world-historical part 
of it, has to be forgone; and this too is at the cost of suffering - his own and other people's. ${ }^{15}$

While one's own suffering need not take the form of death, as it does for Socrates, Iphigenia, and perhaps the saint, it can, in a sense, be much worse than that. Absolute ethics - this 'ethics of foregoing' as Holland calls it ${ }^{16}$ can make one appear cold to one's loved ones, and to have no compassion for their suffering or the suffering of others. After all, if one did feel compassion, it seems that one would act. Thus one can appear to place one's 'integrity' above the needs of others. Is this not itself to fail in one's real obligations out of selfishness, and so not to be good after all?

Such possibilities for limitless suffering - especially, again, that of others - may well be the greatest challenge to any absolute ethics. For it can be very difficult to see that staying true to one's principles is better than bending a little when doing so will prevent or stop others' suffering. The challenge here is, one might say, the challenge of compassion itself, of the sense that we need to eliminate the suffering that comes with a commitment to absolutes through the adoption of a new morality, one of compassion and, consequently, of compromise. Moreover, if the dilemmas of the classroom fail to teach us as great literature might, the dilemmas we find in great literature might themselves present this challenge of compassion most forcefully, for there we might see what happens when an ethics of foregoing and an ethics of compassion come up against one other. Indeed, Sophocles' Ajax may seem to exemplify precisely such a call to give up the inflexibility of absolutes for the sake of compassion, a compassion that would save us from tragedy. There may be tragic elements in the Ajax, but by and large they can seem to be contained within the first half of the play, which ends with Ajax's suicide. The second half can seem like a different play, almost as if tacked on to the first. The interested parties argue over whether Ajax's body should receive proper burial. But unlike Sophocles' Antigone, where the resolution of a similar challenge does constitute a tragedy - precisely a tragedy of infinite suffering, of inflexibility - the resolution in the Ajax - that in spite of Ajax's treachery and suicide, he be given a proper burial - appears decidedly untragic; in the end everyone seems satisfied. All the interested parties in the dispute about Ajax's corpse come to an agreement, orchestrated by Odysseus. To our modern ears, this sounds like an untragic, common-sensical solution to conflict: compromise. Would it not be ridiculous and foolhardy for the parties to do 
anything else? Indeed, the chorus declares, 'There is wisdom in you, Odysseus. Whoever denies it is a fool' (lns. 1560-61). ${ }^{17}$ Where's the tragedy?

I want to pursue this question so as to consider what sort of challenge great literature can at least appear to present to the absolute ethics that Holland articulates. And I want to begin with a reading of the Ajax offered by Herbert Golder. For Golder suggests that the play both calls us to give up an absolute ethics and yet at the same time acknowledges an element of tragedy in our doing so. Eventually, I will suggest that the tragedy of the Ajax goes deeper than Golder thinks. But he gives us a place to start.

II

Aias, the immovable man of honor, is . . . bound to outlive his world, to see it change and time pass him by. He is not 'a man for all seasons.' Achilles is at least spared the pathos of living on in an unheroic age. But Aias lives to see his heroic labors come to nothing. His tragedy, however, is not simply that of individual obsolescence, but also that of a society that sacrifices its highest ideals of honor and nobility to expediency. ${ }^{18}$

If we take Golder's suggestion seriously, then it is possible to see the Ajax as a tragedy, but one of a different kind from the Antigone's tragedy of inflexible absolutes. Instead, we may seem to have a tragedy of 'flexibility': something important is lost in an ethics of compassion and compromise. Seen in this light, that the parties do compromise is what makes the outcome of the play tragic. But, at the same time, compromise seems to be necessary if one is to live with others, and so it is just as well that these 'absolute ideals' are gone.

There are strong hints of this within the play itself. For while no one is completely happy with the result of the compromise (except perhaps Odysseus), it is very difficult to see the solution as anything other than good. Teukros, Ajax's brother, is left to bury the corpse. While he got what he wanted in one sense, a burial, what he really wanted was that Ajax receive the armor of Achilles. It was rightfully his, and as second only to Achilles, he would have received it had Menelaos and Agamemnon not fixed the voting of the judges and given the armor to Odysseus (lns. 481-88, 127073). ${ }^{19}$ That Teukros is allowed to bury the dead hero is, surely, a poor substitute. But it is what is possible, and Teukros is grateful to Odysseus for 
bringing it about: 'You're a noble man, Odysseus. I praise you for all that you've said. How greatly I misjudged you!' (lns. 1570-72). ${ }^{20}$ Menelaos and Agamemnon, on the other hand, are at first unequivocally unsatisfied. Each of them nearly comes to blows with Teukros over Ajax' body. It is only Odysseus' arrival when Agamemnon is about to respond to the last of Teukros' insults that 'loosens this struggle' (ln. 1481). ${ }^{21}$ Taking the side of Teukros, Odysseus says to Agamemnon:

Hear me, then. Before the gods, do not dare to cast this man out unburied, so callously! Never let violence drive you so far in your hate that you tread on justice. I, too, found him hateful once, more than any other man, after I won the armor of Achilles. But though he held to his enmity, I would not repay him now with dishonor, or deny that in my eyes he was the greatest of all who came to Troy, second only to Achilles. If you dishonor him, there can be no justice in it. You will not harm him, you will harm the laws of the gods. To strike at a brave man when he is dead can never be just, no matter how much you hate him. (lns. $1500-18)^{22}$

Agamemnon resists Odysseus' rhetoric about justice, saying that honor requires that Odysseus trample Ajax's body (ln. 1523). ${ }^{23}$ Eventually Agamemnon acquiesces as a result of being asked for a favor. But he is at first thoroughly perplexed by Odysseus' request, for Odysseus appears to be protecting an enemy, placing the interests of Ajax over those of Agamemnon, his friend. Of Ajax Odysseus says, 'My enemy, it's true, yet once he was noble' (lns. 1534-35), ${ }^{24}$ and 'I am moved more by his greatness than by my enmity' (Ins. 1538-39). ${ }^{25}$ For Agamemnon, such instability of opinion makes Odysseus untrustworthy (ln. 1539). ${ }^{26}$ But Odysseus is adamant:

Od: I assure you, most men are that way, now friendly, now hostile.

Ag: And are these the sort of friends you would praise?

Od: I would not praise an obstinate mind!

Ag: You will make us look like cowards.

Od. Not cowards but men of justice - so all the Greeks will call you.

Ag: I must let them bury the body, is that what you say?

Od: It is. I will face the same need some day. (lns. 1540-49, emphasis added) ${ }^{27}$

Agamemnon responds with incredulity: 'It's all one, then, and each man works for himself' (Ins. 1550-51). ${ }^{28}$ Odysseus does not seem to catch the sarcasm in this and replies, 'There is reason in that. Who else should I work for?' (lns. 1551-52). ${ }^{29}$ 
Agamemnon, strikingly like Ajax here, wants to resist Odysseus because of what is required by honor. Odysseus should trample Ajax's body, given that Ajax would happily have tortured and killed Odysseus, and indeed, thought he had done so in his madness. Honor requires that Odysseus prevent the burial of Ajax. But Odysseus does not want this, and this is what is so surprising to Agamemnon. He is not (or is no longer) 'obstinate', but instead is flexible. While recognizing that Ajax is his enemy, he also admires him. He recognizes that all men can be brought low, even Ajax; even nobility is not unchangeable. Consequently, while Ajax is his enemy, he can also 'pity (epoiktirô) the poor wretch' (lns. 147-48). ${ }^{30}$ In fact, this is the lesson that Athena had taught him at the outset of the play. At that point, Odysseus was just as inflexible as the others. Indeed, the play opens with Athena's observation that Odysseus is once again 'hunting out some advantage against [his] enemies' in his pursuit of Ajax (lns. 1-3). ${ }^{31}$ And again at lines 21 and 92 Odysseus describes Ajax as simply his enemy. ${ }^{32}$ But Odysseus softens when he looks directly at Ajax in his madness. And it is Athena who makes him do this (lns. 79-105). ${ }^{33}$ It is seeing Ajax torturing the livestock thinking that it is the Greek army - indeed, hearing Ajax say that he has Odysseus himself inside his tent cowering in chains, that he is about to tie him to a post in the yard and flay him - that moves Odysseus to pity: 'He's yoked to an evil delusion, but the same fate could be mine. I see clearly: we who live are but all phantoms, fleeting shadows' (lns. 14952). ${ }^{34}$

What Odysseus sees in looking directly at Ajax is that he too could be brought low by the gods. He too could be in need of pity and compassion. And this realization allows him to pity Ajax and ultimately persuade Agamemnon to allow Ajax's corpse to receive proper burial. While it is a kind of self-interest that leads to this - Odysseus is willing to forego his right to vengeance so that in the long run he too might escape the justice of the inflexible ancient ideals - it has a happy result. He has transferred his commitment from these absolutes to peace within the community. So, as Agamemnon himself recognizes, this means that Odysseus is now working for himself. But again, as Odysseus himself says, 'There is reason in that. Who else should I work for?' (1551-52). ${ }^{35}$

Odysseus, then, comes to represent a progressive flexibility and thus, too, the end of the kind of tragedy that results from the inflexible ancient ideals of arete; Ajax, Menelaos, and Agamemnon, on the other hand, exemplify 
the 'ancient simplicity' of a life lived by honor. What the intervention of Athena seems to signal is that times have changed: there is no longer room for the bigger-than-life hero Ajax once was. Instead, as Athena says, 'The gods favor wise restraint in men and hate transgressors' (lns. 160-61). ${ }^{36}$

Seen in this light, the Ajax might be considered a creation story, the myth that relates our 'fall' to the kind of ambiguous morality that is now upon us, where men need to be responsive to the changeable world, but then are themselves changeable and so open to the charge of being untrustworthy. And yet while this fall is perhaps tragic in the sense that we have come to live in a world in which expediency and compromise have taken the place of honor and nobility and where what was once considered 'honor and nobility' is now a 'transgression', the point also seems to be that this is just as well. Despite the fact that a kind of self-interest has taken the place of a commitment to honor, surely it is better that all the interested parties give a little and no more blood be shed. Indeed, Golder, while seeing the entire play as a unified tragedy, nonetheless sees in Odysseus' 'each man works for himself' a new morality that 'represents the new ethos of democratic Athens at its best'. ${ }^{37}$ Golder continues: '[Odysseus] speaks as a man who understands that since all men suffer the same fate, compassion and compromise are the appropriate virtues'. ${ }^{38}$ Indeed, even the 'immoveable' Ajax does not seem completely unmoved by the pull of this view. In the course of the first half of the play - in the last few hours of his life - he too learns that nothing is unchangeable. When he first returns to his senses, he seems to be incapable of focusing on anything except his hatred of Odysseus, despite knowing that it was the goddess and not Odysseus who was the cause of his madness: 'Spying everywhere, tool of all evils, filthiest scum of the army. Odysseus, you must be somewhere laughing and gloating now!' (lns. 413-16); ${ }^{39}$ 'O Zeus, father of my fathers, let me kill that skulking schemer and the two high kings, and die!' (lns. 422-26). ${ }^{40}$ But very quickly, in his realization that he is no longer who he was, that fate and the gods have brought him very low, he begins to turn his attention away from Odysseus and to the significance of his own shaming.

The genesis of Ajax's change is found in his interaction with his concubine Tekmessa and, like the change of Odysseus, it is occasioned by pity. Recalling the language from the scene between Hektor and Andromache in the Iliad, Tekmessa tries to persuade Ajax not to die, not to kill himself. The chorus responds to her words with 'If your mind can be moved to pity 
(oikton) as mine is, Aias, you will praise her words' (lns. 587-89). ${ }^{41}$ But Ajax remains aloof: 'She will win my praise if she does what I command' (lns. 589-90). ${ }^{42}$ This turns out to be bringing their son to him, and as it becomes clear to Tekmessa that he really is saying goodbye, she becomes frantic: 'Can't I move you?', 'For god's sake, soften!' (lns. 669, 672). ${ }^{43}$ Again Ajax brushes her words aside: 'It is foolish to think you can school me now!' (lns. 672-73). ${ }^{44}$ But almost immediately, in his famous speech on the nature of time, he admits (to himself alone) that she has in fact moved him, that time changes all, even him:

Great, unfathomable time brings dark things into the light and buries the bright in darkness. Nothing is too strange, time seizes the most dread oath, the most hardened mind. Even I, whose will was tempered like iron, unbending in action, for a woman's sake am become a woman in my speech. Yes, the thought of leaving her a widow, surrounded by enemies, and my son an orphan, moves me to pity (oiktirô). (lns. 712-23)

Like Odysseus, Ajax is moved to pity; he suffers in thinking of their suffering (indeed, his name is apt; as Golder writes, 'Aias (from aiadzein, "to cry in pain"... ) is his destiny"46). He picks up the theme of change again several lines later, appearing to relate his own capacity for change to that of the elemental powers:

And in time to come we will know how to yield to the gods and learn to bow down before the Atreidai. They command and we must obey. For even the most awesome powers submit to authority: snow-tracked winter yields to the rich growth of summer, dark-vaulted night gives way to the shining, white-horsed brightness of day, a blast of appalling wind stills the sea's rage, even alloverwhelming sleep binds only to let go. Then how shall we not learn wiserestraint? (lns. 739-52)

Ajax is no longer immoveable: his pity for a woman has softened his iron will; he has learned how to yield.

All the same, while it is true that Ajax can now be moved, a closer look at these passages reveals that Ajax's lesson is very different from Odysseus'. And this, I think, should make us cautious about accepting Golder's understanding of the Ajax: that 'compassion and compromise are the appropriate virtues ${ }^{48}$ to replace the hard ancient ideals and the 'limitless suffering' that comes with following them. 
For a start, Ajax's compassion for Tekmessa and their son is not the same as the pity that Odysseus feels for Ajax, despite the fact that the same word (cognates of oiktirô) is used to describe both. Ajax feels pity for them because he will be leaving them a widow and orphan surrounded by enemies. He pities them because of his love for them; he does not want to see them suffer. There is nothing self-interested in this. Odysseus, on the other hand, pities Ajax because he realizes that he could face the same need someday; Odysseus' pity is founded on a kind of identification with Ajax that shows his pity to be self-directed, self-interested. These are different forms of pity, so different that it might seem better to call them by different names.

But further, we also need to look more closely at Ajax's use of the elemental powers as a model for his own submission in the Time Speech. For this suggests a submission very different from the submission of Odysseus. Winter 'submits' to summer not by becoming something different, but by removing itself; winter itself does not change. The same is true for night and sleep. These elemental powers are what they are through the change; they retain their identity and their essence. But they give way - they submit - to their opposite. They are like the opposites in Anaximander's surviving fragment: '. . . they pay penalty and retribution to each other for their injustice according to the assessment of Time'. ${ }^{49}$ This is what Ajax seems to take to heart: he must 'go away'; he must die, despite the pity he feels for Tekmessa and their son. He submits by ceasing to be, but it is he, albeit brought low, who ceases to be.

This is not what Odysseus learned from Athena. Instead, for Odysseus, a thing submits by undergoing a change within itself. What Odysseus learned from Athena was that he should be flexible when once he was rigid. And in taking in this lesson, in an important sense, he did cease to be, only not by giving way to an opposite as an elemental power does and as Ajax did. Instead, Odysseus learned to submit, to cease to be, as red paint 'submits' or ceases to be when mixed with yellow. Neither red nor yellow remains through the change; each is completely transformed, as was Odysseus. ${ }^{50}$

Ajax, then, learns to submit, but his submission means that he must 'go away'; for in a vital sense, he has remained 'immoveable'. Odysseus' world cannot accommodate him. But this is not Golder's reading of the play. Golder believes that Odysseus' bold new vision can incorporate 
Ajax's 'ancient simplicity': Odysseus recognizes compassion and compromise as the foundation of society ${ }^{51}$ and . . . is therefore able to adapt even the self-willed exceptional man, Aias, to his democratic vision' ${ }^{52} \mathrm{He}$ continues:

This is not Homeric individualism in the grand manner; but neither is it the opportunistic selfishness of the final years of the Athenian fifth century. It is both political and tragic wisdom: the foundation for a society in which compassion is perceived as the basis of preservation. Thucydides wrote:

...men too often take upon themselves in the prosecution of their revenge to set the example of doing away with those general laws to which all alike can look for salvation in adversity, instead of allowing them to subsist against the day of danger when their aid may be required. (3.84, Crawley transl.)

Odysseus, contrary to expectation, shows how society might preserve not only 'that ancient simplicity into which honor so largely entered' (3.83) but also those endangered 'general laws'.

But does he? As Golder sees it, 'Sophocles refuses full closure' regarding just how 'Odysseus' and 'Ajax' are to 'live together' in this new political reality. ${ }^{54}$ But what could 'full closure' actually look like? How could 'that ancient simplicity' be preserved by those 'appropriate virtues' of 'compassion and compromise'? The question to ask here is what, if anything, can be 'preserved' by compassion and compromise. Indeed, exactly how is compassion itself to be distinguished from 'opportunistic selfishness'? And how is 'compromise' to be distinguished from infinite 'flexibility'? It is not clear that we can see such distinctions at work in Odysseus' 'bold new vision'.

III

Holland himself addresses at least one of these questions. If compassion does not refer to something beyond itself, something beyond, say, a general wish to reduce suffering, then it cannot be distinguished from hedonism. This is so even if one is concerned primarily to reduce the suffering of others. In this form, however, the hedonism can be hidden from us, and so we can be deceived about what we are doing:

In the course of a dialogue concerning the problem of false semblances Plato remarked, to people whom he charged with self-deception, 'You neglect ge- 
ometry' (Gorgias 508A). He was addressing those who did not see goodness as distinct: in particular they did not see it as something distinct from pleasure. Equally they did not see goodness as independent of the will and antithetical to assertion of the self. They were engaged in the pursuit of more (pleonexia), and not necessarily for themselves alone - perhaps this was so in the conversation to which I am alluding, but Plato was mindful of the variant in which they want more for the generality and so put themselves at the service of the social. ${ }^{55}$

While it may appear that helping and fixing and maintaining peace within the community in an Odyssean world is based on a version of the good, without something other than Odyssean compassion at the core, without limits like those found in geometry to ground this compassion - limits that are 'independent of the will and antithetical to assertion of the self' - such compassion can only be governed by the pursuit of pleasure and the avoidance of pain. But it will not be called 'hedonism'. Thus the self-deception, a self-deception maintained by the changing meanings of the words we use to describe the things involved in such compromises. ${ }^{56}$ In the Ajax itself what counts as a 'transgression' is no longer the failure to honor unbending absolutes but the failure to honor men; 'self-restraint' comes to mean submitting to the (incoherent) demands of 'keeping the peace'; 'justice' becomes honoring those who have fallen so that we might all be honored when we fall; 'pity' which once involved the pain of seeing a beloved suffer now means acknowledging the pains of others so as to avoid them oneself. Indeed, Golder himself seems to fall victim to this kind of selfdeception. He believes that Odysseus' 'democratic vision' can incorporate even 'the self-willed exceptional man, Aias'. Golder is calling Ajax by the same name, but the 'Ajax' who can be folded into Odysseus' new morality is now 'self-willed' and 'exceptional', no longer 'noble'. The only way for Ajax to be incorporated is for us to change what he represents. And our doing so creates the illusion that we've been able to pull it off, that we've been able to preserve the absolutes in this new flexible world.

It is especially ironic that Golder appeals to Thucydides here, for that there can be no absolutes in such a world is precisely what Thucydides is trying to show us in the section of his text quoted by Golder above. Even in considering a text that shows the incoherence of an 'absolute' that is selfregarding, Golder appears to be taken in by it. This is Thucydides' famous discussion of the civil strife (stasis) of the cities on the island of Corcyra (3.82), where he brings out that in such times of adversity, not only do men do away with the absolutes that would offer salvation, but that this itself is 
disguised by the changing meanings of words: 'Words had to change their ordinary meaning and to take that which was now given them' (3.82.4). ${ }^{57}$ And while Thucydides is speaking here of the worst of times - civil war or stasis - Plato shows how the same thing can happen to the individual whenever there is an analogous civil war within the soul, linking it to compromise, and even suggesting that these psychic civil wars can get their start in a kind of compassion. By way of conclusion it might be worth spelling this out in some detail.

In his description of the degeneration of the best city in Republic Book VIII, Plato writes that once conflict arises between its best and worst parts, the 'perfect city' goes 'to the middle' (eis to meson). It finds a place between the two opposed camps. It compromises:

Once division (stasis) had come on the scene ... the two strains of iron and bronze in their race each pulled them in the direction of moneymaking and of acquiring land and houses and gold and silver, while the other two strains of gold and silver, inasmuch as they weren't needy but rich in their souls by nature, led them toward virtue and the ancient order of things. When they came into violence and strife against one another, they agreed to a compromise. $(547 \mathrm{~B})^{58}$

The 'middle' here is a city dominated by spiritedness (548C). But this means that the rulers and guardians became flexible when they should have remained steadfast. The same progression occurs with each new degeneration of the city and, analogously, of the soul: conflict (stasis), or sometimes even just the threat of it, occasions a compromise. But this compromise is always between a better and worse part: we become lovers of honor through a compromise between loving wisdom and loving money; we become lovers of money by compromising our love of honor and our other desires $(550 \mathrm{E})$; we become democratic through a compromise between loving money and our worst desires (572C-D). Each move 'to the middle' takes us further away from the unchangeable absolutes. But it is already in the first degeneration - from loving wisdom to loving honor - that we have ceased to use external limits and instead have become self-regarding. Thus the door is opened to pleonexia from the start.

But that this is what is happening is disguised by the fact that we use the same words to describe the result as we used to describe what we have done away with; what comes with each compromise within the soul is a 
shift in the meanings of words. Plato illustrates this in his description of the battle between necessary and non-necessary desires within the soul of the youth who ultimately becomes 'democratic':

Once [the non-necessary desires] come out on top in battle, don't they give shame the name simplemindedness, and push it out, a refugee without honor; don't they call moderation unmanliness, fling mud at it, and throw it out; and don't they persuade the young person that a sense of proportion and orderliness in spending money is unsophisticated and slavish ...? ... [T]hey ... escort insolence, anarchy, wastefulness, and shamelessness back in, crowned with wreaths, in a torch-lit procession, accompanied by a vast chorus singing their praises and giving them pretty names, calling insolence high education, anarchy freedom, wastefulness flamboyant style, and shamelessness courage. (560D-E)

I said at the outset that Plato believes that compassion can lead to such stasis in the soul and so to the sorts of compromises that involve us in the changing of the meanings of words. This, I take it, is behind his objections in Republic Book X to our watching certain kinds of tragedy on the stage. For in identifying and so sympathizing with such characters we strengthen that part of the soul that likes to grieve when we undergo misfortune ourselves. As he writes, ' . . . few are capable of reflecting that what we enjoy in others will inevitably react upon ourselves. For after feeding fat the emotion of pity there, it is not easy to restrain it in our own sufferings' (606B). This initiates just the sort of conflict within the soul that Plato is describing in Book VIII. But it is important to see that Plato is not rejecting all forms of pity. Both in the Republic as well as other dialogues Socrates either himself pities or says that it is appropriate to pity those who are ignorant. ${ }^{59}$ They are truly suffering a misfortune. And the kind of ignorance that is pitiable is the kind that is hidden from the person who suffers it; it is the kind involved in 'thinking you know when you don't'. But this is the kind involved in just the sort of self-deception that we have been discussing. It is sad that someone is living his life as if asleep. But like Ajax's pity for Tekmessa, this pity does not turn on any identification with the sufferer.

The kind of compassion that Plato rejects, then, is the kind that directs one's attention to the self, as did Odysseus' compassion for Ajax. For in strengthening the fear that misfortune may come one's way and in suggesting the notion that the proper attitude toward such misfortune is indignation - the very attitude of those 'fretful' characters portrayed on stage 
$(604 \mathrm{D}, 605 \mathrm{~A}, \mathrm{D})$ - not only is one more likely to be immoderate when one undergoes misfortune oneself - which signals that stasis between the parts of the soul has begun - but one is also more likely to try to arrange things so that such pain and suffering are avoided (both for oneself and for others). Like the moral dilemmas discussed at the outset of this paper, this self-regarding compassion gets consequentialist thinking started. It involves one in what in the Phaedo (68B-69E) Socrates calls 'false virtue'. This is the exchange of pleasure for pleasure, pain for pain, fear for fear 'as if they were coins' (69A). ${ }^{60}$ But this, Socrates says, is 'absurd', 'impossible" (atopos, alogon, adunaton, 68D-E). It is to be virtuous through vice: 'to be self-restrained through a kind of self-indulgence' (68E); to be courageous through cowardice (68D). We think we are doing what will give us what we want, what is best (no pain or suffering either for ourselves or others or both), and our words reflect this. It is what we call 'courage' or 'moderation'. But this, as Holland himself says, is nonsense to Plato. It is like saying 'I must not do it but I must do it' ${ }^{61}$ But in making these calculations with such coins we fool ourselves into thinking that we can know the consequences of our actions beforehand and thus that such calculations justify what we are about to do.

It is for these reasons that Odysseus' morality is, I think, deceptive. It is a world of false virtue, but one in which this fact is itself concealed because these phantoms of virtue are not given their true names. Hence its seductiveness. Indeed, if there is anything tragic about Sophocles' Ajax, it does not seem right to say that it is found in any hubris of Ajax. Nor that it lies in the purported 'fact' that we must give up our absolutes in order to get on with things. Instead, it seems that what is tragic in Sophocles' Ajax is the hubris of this Odyssean attempt to fix things and the self-deception that goes with it. And so Holland seems to be right; to be good is to yield. But this is the yielding of Ajax, not that of Odysseus. This is the 'ethics of foregoing'. And while there is something tragic in it - the tragedy of 'limitless suffering' - there is not the tragedy of self-deception. ${ }^{62}$ 


\section{NOTES}

${ }^{1}$ R. F. Holland, 'Absolute Ethics, Mathematics and the Impossibility of Politics', in Against Empiricism: On Education, Epistemology and Value, (New Jersey, 1980), pp. 126-142. (Hereafter 'Absolute Ethics'.) The passage quoted is taken from page 133.

${ }^{2}$ R. F. Holland is Emeritus Professor at the University of Leeds. He taught at University College, Swansea, from 1950 to 1965 and is an Honorary Fellow of the University of Wales, Swansea. He is past president of the Aristotelian Society and of the Mind Association and edited the Routledge series Studies in Philosophical Psychology in which appeared, among other works, Peter Winch's The Idea of a Social Science and M. O'C. Drury's The Danger of Words.

${ }^{3}$ Williams in Smart and Williams: Utilitarianism For and Against, p. 98, as quoted by Holland in 'Absolute Ethics', pp. 138-139.

4 'Absolute Ethics', p. 138.

${ }^{5}$ R. F. Holland, 'Morality and the Two Worlds Concept', in Against Empiricism: On Education, Epistemology and Value, pp. 75-91. (Hereafter 'Morality'.)

${ }^{6}$ What Kierkegaard means by an 'eternal resolution' is, Holland writes, one that is unconditional, and has nothing to do with probabilities or with 'the upshot': 'It is not a resolution whose actuality or effectiveness is judgeable in terms of what it accomplishes: it is not concerned at all with what is outward, with one's success or progress in the world' ('Morality', p. 77).

7 'Morality', p. 78.

${ }^{8}$ Ibid.

9 'Absolute Ethics', p. 137.

${ }^{10}$ Ibid., p. 138.

${ }^{11}$ Ibid., p. 140.

${ }^{12}$ Ibid.

${ }^{13}$ Ibid., p. 141.

${ }^{14}$ Ibid., p. 142.

${ }^{15}$ Ibid., p. 137.

${ }^{16}$ Ibid.

${ }^{17}$ Sophocles, Aias (Ajax), as translated by Herbert Golder and Richard Pevear, (Oxford, 1999). Please note that the line numbers in the Golder/Pevear translation are different from those in the Greek text. I have used their line numbers in the body of the paper, and included the standard Greek line numbers for each quotation in the notes. The current passage can be found at lines 1374-75.

${ }^{18}$ From the Introduction to Sophocles, Aias (Ajax): p. 5. (Hereafter, 'Intro.')

${ }^{19}$ Lns. 441-46, 1135-37.

${ }^{20}$ Lns. 1381-82.

${ }^{21}$ Ln. 1317.

${ }^{22}$ Lns. 1332-45.

${ }^{23}$ Ln. 1348.

${ }^{24}$ Ln. 1355.

${ }^{25}$ Ln. 1357.

${ }^{26}$ Ln. 1358. 
${ }^{27}$ Lns. 1359-65.

${ }^{28}$ Ln. 1366.

${ }^{29}$ Ln. 1367.

${ }^{30}$ Lns. 121-22.

${ }^{31}$ Lns. 1-2.

${ }^{32}$ Lns. 18 and 78.

${ }^{33}$ Lns. 66-88.

${ }^{34}$ Lns. 123-26.

${ }^{35}$ Ln. 1367.

${ }^{36}$ Lns. 132-33.

37 'Intro.', p. 20.

${ }^{38}$ Ibid.

${ }^{39}$ Lns. 379-82.

${ }^{40}$ Lns. 387-91.

${ }^{41}$ Lns. 525-26.

${ }^{42}$ Lns. 527-28.

${ }^{43}$ Lns. 592, 594.

${ }^{44}$ Lns. 594-95.

${ }^{45}$ Lns. 646-53.

46 'Intro.', p. 10. Cf. Ins. 468-72 (Greek lns. 430-33).

${ }^{47}$ Lns. 666-77.

48 'Intro.', p. 20.

${ }^{49}$ DK $12 \mathrm{~A} 9$, as translated by G. S. Kirk, J. E. Raven, and M. Schofield in The Presocratic Philosophers: A Critical History with a Selection of Texts, Second Edition, (Cambridge, 1983), and found in their edition as Anaximander fragment 101A.

${ }^{50}$ We can, perhaps, see Ajax's understanding of 'flexibility' or submission most clearly in the context of his attitude towards his sword. He needs, he says, to be purified; he needs to bury his sword, 'the most hostile of weapons, where no one will find it' (lns. 730-31, or Greek lns. 658-59). The story behind this sword is significant, I think. For this is the sword that Ajax received from Hektor. At the end of the first day of fighting in the Iliad, Ajax and Hektor are in mortal combat. One of them would surely have died had it not been for heralds, sent by both sides - 'messengers of Zeus and men' (VII. 274) - who put an end to the fighting for the day: 'Fight no more, dear sons, and do not do battle; both of you are loved by Zeus, the cloud-gatherer, and both are spearmen; that surely we all know now. Moreover night is now upon us, and it is well to obey night' (VII. 279-282, translated by A. T. Murray (revised by William F. Wyatt) in Homer: Iliad, Books 1-12, Loeb Classical Library (Cambridge, MA, 2003, second edition first published 1999)). Hektor obeys, and proposes that he and Ajax exchange gifts so that many Achaeans and Trojans may say: 'The two fought in rivalry of soul-devouring strife, but then made a compact and parted in friendship' (VII. 01302). Ajax agrees and gives Hektor his belt; Hektor gives Ajax the sword. For both, however, the gifts are the beginnings of their ends. Ajax speaks of this in the Time Speech: 'Let night and Hades keep it safe from all eyes, for I swear since the day I took it in gift from Hektor, my greatest enemy, I have had no love from the Greeks. It 
is true, then: an enemy's gift is no gift but a bringer of loss' (lns. 732-38 or Greek lns. 660-65). Hektor might well have said the same thing, for it was Ajax's belt that was used to drag him around the walls of Troy. Reflecting on this, at the end of his speech, Ajax seems to put a different spin on Odysseus' lesson. He says the following: 'I know now to hate an enemy just so far, for another time we may befriend him. And the friend I help, I will not help too greatly, knowing that one day may find him my enemy. For most mortals friendship is a treacherous harbor' (lns. 753-59 or Greek lns. 678-83). It sounds here as if Ajax has taken on Odysseus' view of friendship. But his actions show that this is not so. Instead, these words signal his understanding of who and what Odysseus is, and that the world had undergone an irreversible change. For even the sword has changed its meaning. When he exchanged gifts with Hektor, the sword signified the hard ancient simplicity - the kind of life where conflict leads to battle, but where there is nobility and admiration of strength, even in one's enemies. Indeed, the impersonal nature of battle seems to have made this possible. Since the warriors were fighting for something other than themselves, they were able to recognize and even celebrate the excellences of their enemies, and not only for the reason that a greater glory goes to him who defeats such an excellent enemy (although this was part of it). But given how the world has changed, the sword now represents Odysseus' new morality. For 'friendship' between two enemies has taken on a new meaning. This, I take it, is the point of Ajax's words quoted above (lns. 753-59, or Greek lns. 678-83). Now such friendships are made with a view to expediency and the attempt to get what one wants. Ajax can do nothing to prevent the reign of Odysseus' morality, but he can bury the sword that he now recognizes has come to take on this new meaning.

${ }^{51}$ 'Intro.', p. 21.

52 'Intro.', p. 20.

53 'Intro.', p. 21. For the full citation of Thucydides, see note 57 below.

${ }^{54}$ Ibid.

55 'Absolute Ethics', pp. 131-32.

${ }^{56}$ Compare Holland: 'What gives to the problem of spurious semblances its depth is the fact that in many circumstances the relative presents itself as indistinguishable from the absolute. When the pursuer of advantage is fighting his way up it is obvious that his power is only relative and we should not think of calling it anything else however vigorous he may be. But once he has got to the top and become a dictator, his power is 'absolute' (we call it that because we no longer see any relativity in it). He has absolute power in the state' ('Absolute Ethics', p. 133).

${ }^{57}$ Translated by Richard Crawley as found in The Landmark Thucydides: A Comprehensive Guide to the Peloponnesian War, (ed. Robert B. Strassler) (New York, 1998).

${ }^{58}$ Translated by Paul Shorey in Plato: The Republic, Volume II (Books VI-X), Loeb Classical Library (Cambridge, MA, 1987, first published 1935).

${ }^{59}$ See, for example, Republic 518B.

${ }^{60}$ Translated by Harold North Fowler in Plato: Euthyphro, Apology, Crito, Phaedo, Phaedrus, Loeb Classical Library (Cambridge, MA, 1995, first published 1914).

${ }^{61}$ 'Absolute Ethics', p. 136. 
${ }^{62}$ I am indebted to Dan Tkachyk and John Edelman for helping me to work through the ideas of this paper. Most of the points and connections that I attempt to bring out here would not be half as clear as I hope they now are had they not been the generous and astute listeners and readers that they are.

\section{WORKS CITED}

Holland, R. F. Against Empiricism: On Education, Epistemology and Value. Oxford. 1980.

Plato. The Republic. Volume II (Books VI-X). Translated by Paul Shorey. Loeb Classical Library. Cambridge, MA. 1987 (First published 1935).

Euthyphro, Apology, Crito, Phaedo, Phaedrus. Translated by Harold North Fowler. Loeb Classical Library. Cambridge, MA. 1995 (First published 1914).

Sophocles. Aias (Ajax), as translated by Herbert Golder and Richard Pevear. Oxford, 1999.

Thucydides. The Landmark Thucydides: A Comprehensive Guide to the Peloponnesian War. Ed. by Robert B. Strassler. New York. 1998. 